\title{
ACKNOWLEDGMENTS
}

A large number of systematic ichthyologists, many curators of natural history museums, and an editor have made major contributions to this work, and their inputs are gratefully acknowledged. Stuart Poss critically read the scorpaeniform section and offered numerous comments. William Richards read the triglid and peristediid sections, provided unpublished manuscripts, and made many valuable suggestions. G. David Johnson and William SmithVaniz offered several corrections to the key to the families of Perciformes. Tom Orrell read the centropomid and inermiid sections and offered advice. Phil Heemstra reviewed most of the serranid section and provided unpublished manuscripts on moronids, acropomatids, and howellids of the western Central Atlantic. Phil Lobel provided input on the Hyploplectrus (Serranidae) species accounts. Offer Gon reviewed the apogonid and epigonid sections. William Anderson, Jr., read the anthiine serranid, lutjanid, and symphysanodontid sections and provided unpublished manuscripts on anthiine serranids and lutjanids of the western Central Atlantic. William Smith-Vaniz read the carangid section and provided an unpublished manuscript on the carangid fishes of the western Central Atlantic. Labbish Ning Chao provided an unpublished manuscript on the sciaenids of the western Central Atlantic. Randy Mooi critiqued the grammatid and pempherid sections. Bruce B. Collette read the pomatomid, coryphaenid, echeneid, rachycentrid, and scombrid sections; furnished data concerning these taxa; and provided unpublished manuscripts on pomatomids, coryphaenids, rachycentrids, and echeneids of the western Central
Atlantic. Richard E. Matheson read and offered clarifications on the centropomid, gerreid, and sciaenid sections. Mark Leiby and Richard Matheson critiqued and provided data for the sparid section. Mark Westneat critiqued the labrid and scarid sections and provided unpublished manuscripts of the labrids and scarids of the western Central Atlantic. Jeffrey T. Williams read and offered substantial improvements to the very long-winded blennioid sections. Karsten Hartel read and commented on the callionymid and draconettid sections. Edward O. Murdy provided keys to the eleotrids and gobiids of the western Central Atlantic and read the long and tedious gobioid sections. Richard Haedrich read and commented on the stromateoid sections. Thomas A. Munroe read the pleuronectiform sections and provided helpful comments. These colleagues have greatly improved the reliability of the nomenclature and taxonomic treatments in the book. Special thanks are given to Nancy Warrington for her excellent editorial assistance on both volumes of this work. Any remaining problems are strictly the fault of the authors.

Various colleagues made available lists of species either that they have recorded from the western Central Atlantic or the Gulf of Mexico or that reside in their natural history collections. William Richards and Mark Leiby provided a list of ray-finned fishes occurring between Cape Hatteras, NC, and the equator. John W. Tunnell, Jr., supplied a checklist of fishes inhabiting the coral reefs of the southwestern Gulf of Mexico that he, Mary E. Vega, and John E. Gourley prepared. Karsten Hartel provided a listing of the species of fishes from 
the Gulf of Mexico housed at the Museum of Comparative Zoology (MCZ), Cambridge, MA. Mary Ann Rogers furnished a list of the holdings of fishes of the Gulf of Mexico housed at the Field Museum of Natural History (FMNH), Chicago, IL. Rob Robins supplied a list of the fishes of the Gulf of Mexico housed at the Florida Museum of Natural History (FM), Gainesville, FL. Jeffrey T. Williams made available computer records of the species of fishes of the Gulf of Mexico residing at the National Museum of Natural History (USNM), Washington, D.C. Dan Allen made available a video record of Harriota raleighana from off Louisiana.

Glen Parsons, G. W. Lingram, Jr., and R. Havard provided the authors with a prepublication copy of their manuscript describing the record capture of Mitsukurina owstoni (Mitsukurinidae) in the Gulf of Mexico. Tracy Ward, Erik Cordes, and Chuck Fisher, Penn State University, provided specimens of Bellottia apoda (Bythitidae) from the Gulf of Mexico.

The following curators are thanked for their hospitality during our visits to their collections and for loaning us specimens: Melanie Stiassny, Scott Schaeffer, and Barbara Brown (AMNH); Bernard Kuhajda, Phillip Harris, and Herbert Boschung (UAIC), Barry Chernoff, Mary Ann Rogers, and Kevin Shlagle (FMNH); Richard E. Matheson and Mark Leiby (FBC); George H. Burgess and Rob Robins (FM); Stuart Poss and Sara LeCroy (GCRL); Karsten Hartel and Ann Everly (MCZ); Randy Mooi (MPM); John Lundberg, Dominique Didier, William G. Saul, Mark Sabaj, and Eugenia Böhlke (ANSP); Kathryn Vaughan and Heather Prestridge (TCWC); Dean Henderson (TNHC); Hank Bart and Mike Taylor (TU); Héctor Espinosa Pérez and Leticia Huidobro-Campos (UNAM); Susan Jewett, Lisa Palmer, David Smith, and Jeffrey T. Williams (USNM). Heather Prestridge also provided valuable assistance in elec- tronically adapting and labeling many of the illustrations. Natural history collection acronyms are according to Leviton et al. (1985).

Students of John D. McEachran whose tenure overlapped this project and who contributed to the effort include the following: Jeff Childs, Timothy Clark, Kathy Dunn, and Hera Konstantinou. Neil Ashilman, an undergraduate student, produced the line drawings of Moronidae and Howellidae that accompany the key to the family of percoid fishes.

Several individuals were very instrumental in assisting the authors in obtaining funds for publication of the second volume: Rezneat Darnell, Emeritus Professor, Texas A\&M University; Benny Galloway, President of LGL Associates, Bryan, TX; James P. Ray, Manager of Environmental Ecology and Response Shell Global Solutions (US), Inc.; John W. Tunnell, Jr., Associate Director, Harte Institute for Gulf of Mexico Studies, TAMU-Corpus Christi; and Alan Verret, Executive Director, Offshore Operators, New Orleans, LA.

Permission to reproduce copyrighted figures was provided by: Species Identification and Data Center of the Fisheries, Food, and Agriculture Organization (FAO) of the United Nations; Academy of Natural Sciences, Philadelphia; and the National Museum of Natural History, Smithsonian Institution.

Financial support from the National Science Foundation (NSF), Texas A\&M University Sea Grant Office, and Coastal Conservation Association (CCA) enabled the completion of the second and final volume of Fishes of the Gulf of Mexico. Without this support, it would not have been possible to complete the illustrations of the fish species, make numerous visits to natural history institutions housing specimens of fishes from the Gulf of Mexico, and purchase the computers and supplies needed to complete the text in a timely fashion. 


\section{Fishes of the Gulf of Mexico}

Volume 2 
THIS PAGE INTENTIONALLY LEFT BLANK 